\title{
Partial Purification and Some Properties of ATP:Citrate Lyase from the Oleaginous Yeast Lipomyces starkeyi
}

\author{
By CHRISTOPHER A. BOULTON* AND COLIN RATLEDGE \\ Department of Biochemistry, University of Hull, Hull HU6 7RX, U.K.
}

(Received 31 January 1983; revised 16 May 1983)

\begin{abstract}
ATP : citrate lyase has been purified some 20 -fold from the oleaginous yeast, Lipomyces starkeyi CBS 1809. The enzyme, which is labile, was stabilized by the addition of ATP and citrate to extraction buffers. Michaelis-Menten kinetics were exhibited towards ATP and citrate. The molecular weight of the enzyme was determined to be approximately 510000 . There was a specific requirement for ATP for activity. No activity was observed in the absence of $\mathbf{M g}^{2+}$, although $\mathrm{Co}^{2+}$ and $\mathrm{Mn}^{2+}$ could partially substitute for $\mathrm{Mg}^{2+}$. ADP inhibited activity $(50 \%$ inhibition at $1 \mathrm{mM})$, as did long-chain fatty acyl-CoA esters $(50 \%$ inhibition with $4 \mu \mathrm{M}$ oleoyl$\mathrm{CoA}$ ). The possibility of control of ATP : citrate lyase activity by fluctuations in the prevailing energy charge or by changes in the intracellular concentrations of long-chain fatty acyl-CoA esters is discussed.
\end{abstract}

\section{INTRODUCTION}

ATP : citrate lyase (EC 4.1.3.8; ATP : citrate oxaloacetate-lyase CoA-acetylating and ATPdephosphorylating) catalyses the ATP-dependent cleavage of citrate to acetyl-CoA and oxaloacetate. The enzyme, which is widely distributed in both plant and animal tissues (Srere, 1975) catalyses the first reaction in the pathway of cytosolic lipogenesis by providing precursor acetylCoA units which are themselves derived from intramitochondrial citrate. Evidence for the involvement of ATP : citrate lyase in lipogenesis has principally been provided by studies with mammalian systems. In early studies (Kornacker \& Lowenstein, 1963, 1965) it was reported that the observed activity of rat hepatic ATP : citrate lyase positively correlated with altered rates of lipogenesis produced by dietary manipulation. Subsequently, it has been shown that this is an induction-repression process (Yen \& Mack, 1980). Rat hepatic ATP : citrate lyase has a molecular weight of 540000 , consists of four identical subunits and has been identified as a phosphoprotein (Linn \& Srere, 1979). The structural phosphate is distinct from enzyme-bound phosphate derived from ATP during the reaction and may appear as a consequence of hormonemediated phosphorylase reactions (Janski et al., 1979).

Our interest in ATP : citrate lyase has arisen as a consequence of studies of the biochemistry of lipid accumulation in oleaginous micro-organisms. In a previous report (Boulton \& Ratledge, $1981 a$ ) we have provided evidence that ATP : citrate lyase is found only in yeasts capable of accumulating substantial amounts of lipid under optimal cultural conditions $(\geqslant 20 \%$, w/w $)$. In the same report evidence was provided that ATP:citrate lyase may catalyse the ratedetermining step in the sequence of reactions leading to triacylglycerol biosynthesis in a typical oleaginous yeast, Lipomyces starkeyi. In a preliminary report (Boulton \& Ratledge, 1981 b), it was shown that ATP : citrate lyase from $L$. starkeyi was strongly inhibited by long-chain fatty acylCoA esters and that this phenomenon may be of regulatory significance in controlling triacylglycerol biosynthesis in oleaginous yeasts. The present paper presents the results of a more detailed study of the properties of ATP : citrate lyase partially purified from the same yeast. 


\section{METHODS}

Yeast and growth. Lipomyces starkeyi CBS 1809 was grown at $30^{\circ} \mathrm{C}$ in a five litre chemostat using a glucose/salts medium under nitrogen-limitation, as previously described by Botham \& Ratledge (1979), with a dilution rate of $0.05 \mathrm{~h}^{-1}$ and the $\mathrm{pH}$ maintained at 5.5 by the automatic addition of $\mathrm{NaOH}$.

Preparation of extracts. Washed yeast was suspended in $50 \mathrm{~mm}-\mathrm{Tris} / \mathrm{HCl}, \mathrm{pH} 7 \cdot 5$, containing $10 \mathrm{mM}-\mathrm{MgCl}_{2}$, $10 \mathrm{~mm}$-dithiothreitol, $1 \mathrm{~mm}$-ATP and $20 \mathrm{~mm}$-tripotassium citrate and a cell-free extract prepared using a French pressure cell (Boulton \& Ratledge, 1980).

Enzyme assay. ATP : citrate lyase activity was measured by the coupled spectrophotometric procedure of Srere (1962).

Protein estimation. Protein was assayed by the dye-binding procedure of Bradford (1976) using $\gamma$-globulin as standard.

Enzyme purification. In a typical purification (see Table 1), $250 \mathrm{ml}$ culture was removed from the chemostat which yielded approximately $20 \mathrm{~g}$ (wet wt) cells after harvesting and washing. The extract was prepared, and all procedures were carried out, at $4{ }^{\circ} \mathrm{C}$. Solid $\left(\mathrm{NH}_{4}\right)_{2} \mathrm{SO}_{4}\left[2 \cdot 26 \mathrm{~g}(\mathrm{ml} \text { extract })^{-1}\right]$ was added to the stirred extract over a period of $15 \mathrm{~min}$ to give $40 \%$ saturation. After a further $15 \mathrm{~min}$ stirring, the precipitate was sedimented by centrifuging at $30000 \mathrm{~g}$ for $10 \mathrm{~min}$. The precipitate was dissolved in a minimum volume of $20 \mathrm{mM}-\mathrm{Tris} / \mathrm{HCl}$, $\mathrm{pH} 7 \cdot 5$, with the additives already described, and applied to a Sepharose-4B column $(2.5 \times 40 \mathrm{~cm})$ equilibrated in similar buffer. After elution, active fractions were pooled and applied to a DEAE-Sephadex (A50) column ( $2 \times$ $50 \mathrm{~cm}$ ) equilibrated in $20 \mathrm{~mm}-\mathrm{Tris} / \mathrm{HCl}, \mathrm{pH} \mathrm{7 \cdot 5}$, containing additives. ATP : citrate lyase was recovered in the wash-through peak and was stored at $4{ }^{\circ} \mathrm{C}$.

Determination of enzyme purity. The purity of the enzyme preparation was gauged by polyacrylamide disc gel electrophoresis, as previously described (Boulton \& Ratledge, 1980).

Calibration of Sephacryl-S300 column for determination of molecular size of ATP : citrate lyase. The column $(2 \cdot 5 \times$ $90 \mathrm{~cm}$ ) was equilibrated in $50 \mathrm{mM}-\mathrm{Tris} / \mathrm{HCl}, \mathrm{pH} 7.5$, and the void volume determined using $5 \mathrm{ml} 0.2 \%$ (w/v) Blue Dextran (Pharmacia) in the same buffer. The peak of the eluted dye was determined spectrophotometrically at $630 \mathrm{~nm}$. The following proteins were used as standards, assumed molecular weights are given in parentheses: $\beta$ galactosidase (Sigma, grade VI), $3 \mathrm{mg}$ (520000); urease (Sigma, type III), $30 \mathrm{mg}$ (490000); phosphorylase-a (Sigma), $5 \mathrm{mg}$ (370000); pyruvate kinase (Sigma, type II), $5 \mathrm{mg}$ (235000) and thyroglobulin (Sigma, type I), $30 \mathrm{mg}$ (669000). Proteins were dissolved in $5 \mathrm{ml} 50 \mathrm{~mm}$-Tris/ $\mathrm{HCl}, \mathrm{pH} 7.5$ and, following elution in similar buffer, were detected spectrophotometrically at $280 \mathrm{~nm}$ and also by the specific assay procedures as described by Bergmeyer (1974).

\section{RESULTS AND DISCUSSION}

\section{Stabilization of ATP : citrate lyase}

Initial attempts to purify ATP : citrate lyase from $L$. starkeyi using only Tris/ $\mathrm{HCl}$ buffer were hindered by the apparent instability of the enzyme such that even the simplest fractionation procedures resulted in unacceptable losses of activity. The addition of thiol-containing reagents and/or $\mathrm{Mg}^{2+}$ ions to extraction buffers, which have been reported to stabilize rat hepatic ATP : citrate lyase (Inoue et al., 1966; Plowman \& Cleland, 1967), did not alleviate the problem. It has been reported more recently that ATP : citrate lyase from germinating castor bean endosperm is also unstable but that the addition of citrate to extraction buffers exerted a stabilizing effect (Fritsch \& Beevers, 1979).

Citrate was also observed to stabilize ATP : citrate lyase from $L$. starkeyi, as did ATP, but to a lesser extent. However the maximum effect was noted when the two substrates were used in combination. Thus, enzyme stored at $4{ }^{\circ} \mathrm{C}$ in $50 \mathrm{mM}$-Tris/ $\mathrm{HCl}$, pH $7 \cdot 5$, containing $1 \mathrm{mM}-\mathrm{MgCl}_{2}$ and $10 \mathrm{~mm}-2$-mercaptoethanol lost $83 \%$ of its activity in $48 \mathrm{~h}$. However, the addition of $1 \mathrm{mM}-$ ATP or 20 mM-tripotassium citrate to extracts reduced the loss of activity, over the same period, to $52 \%$ and $30 \%$, respectively. Furthermore, when $1 \mathrm{mM}$-ATP and $20 \mathrm{mM}$-tripotassium citrate were added in combination, $91 \%$ of the activity remained after $48 \mathrm{~h}$ storage at $4{ }^{\circ} \mathrm{C}$. Consequently, tripotassium citrate and ATP at final concentrations of $1 \mathrm{~mm}$ and $20 \mathrm{~mm}$, respectively, were included in all buffers used for the extraction, purification and subsequent storage of the enzyme.

\section{Partial purification of ATP : citrate lyase}

The average values of five individual purifications, all of which gave broadly similar results, are shown in Table 1 . The purified enzyme as judged by polyacrylamide disc gel electrophoresis, 
Table 1. Partial purification of ATP : citrate lyase from L. starkeyi

\begin{tabular}{|c|c|c|c|c|c|c|}
\hline Fraction & $\begin{array}{l}\text { Volume } \\
\text { (ml) }\end{array}$ & 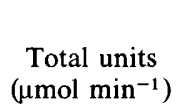 & $\begin{array}{l}\text { Total } \\
\text { protein } \\
\text { (mg) }\end{array}$ & $\begin{array}{c}\text { Specific activity } \\
{\left[\mu \mathrm{mol} \mathrm{\textrm {min } ^ { - 1 } ( \mathrm { mg } \text { protein }}{ }^{-1}\right]}\end{array}$ & $\begin{array}{l}\text { Purification } \\
\text { factor }\end{array}$ & $\begin{array}{l}\text { Yield } \\
(\%)\end{array}$ \\
\hline Crude & $27 \cdot 5$ & $11 \cdot 0$ & $236 \cdot 0$ & $0 \cdot 047$ & $1 \cdot 0$ & 100 \\
\hline $0-40 \%\left(\mathrm{NH}_{4}\right)_{2} \mathrm{SO}_{4}$ & $4 \cdot 8$ & $9 \cdot 0$ & $68 \cdot 2$ & $0 \cdot 132$ & $3 \cdot 0$ & 90 \\
\hline $\begin{array}{l}\text { Pooled Sepharose } 4 B \\
\text { eluate }\end{array}$ & $60 \cdot 0$ & $8 \cdot 4$ & $29 \cdot 4$ & 0.286 & $6 \cdot 0$ & 76 \\
\hline Pooled DEAE-Sephadex & $48 \cdot 2$ & $6 \cdot 3$ & $6 \cdot 8$ & 0.922 & $20 \cdot 0$ & 57 \\
\hline
\end{tabular}

was not homogeneous; at least seven protein bands were visible and no single major band was evident. However, it was free from contaminating activities of citrate synthase, adenylate kinase, acetyl-CoA deacylase and acetyl-CoA synthetase. The preparation did, however, contain malate dehydrogenase [specific activity $0.5 \mu \mathrm{mol} \mathrm{min}^{-1}(\mathrm{mg} \text { protein })^{-1}$ ], but as this enzyme was a necessary constituent of the assay system it was not considered to be of serious consequence. It is appreciated that this purification was modest compared with those made with ATP : citrate lyase purified from mammalian sources, where affinity techniques such as the use of Cibacron blue Sepharose have been successfully applied (Hoffmann et al., 1979; Redshaw \& Loten, 1981). However, the necessity to stabilize the yeast enzyme by the addition of substrates, during the purification, had the consequence that no binding to this gel was observed, thus rendering this particular method inapplicable.

\section{Properties of the enzyme}

Variation of enzyme activity with $\mathrm{pH}$. The response of ATP : citrate lyase activity to changes in $\mathrm{pH}$ was similar to that reported for the rat hepatic enzyme (Inoue et al., 1966). Maximum activity was observed between $\mathrm{pH} 8.2$ and $\mathrm{pH} 8.6$ and activity was reduced to $50 \%$ at $\mathrm{pH} 7.3$ and $\mathrm{pH} 9 \cdot 5$. Consequently, $\mathrm{pH} 8.4$ was judged suitable for subsequent assays.

Initial velocity as a function of substrate concentrations. Lineweaver-Burk plots were linear with respect to both ATP and citrate concentrations. Apparent $K_{\mathrm{m}}$ values were calculated to be $135 \mu \mathrm{M}$ and $70 \mu \mathrm{M}$ for ATP and citrate, respectively. It was not possible to determine the apparent $K_{\mathrm{m}}$ for coenzyme A because non-saturating concentrations of this substrate were so low that rates rapidly became non-linear, thus making initial velocity measurements unreliable.

The apparent $K_{\mathrm{m}}$ values for ATP and citrate were of a similar order to those reported for the human, rat and avian enzymes (Hoffmann et al., 1980a, $b$; Inoue et al., 1966) as well as those reported for the enzyme from the mould Penicillium spiculisporum (Mahlén, 1973). However, the non-linear response, reported when citrate was the variable substrate, with the enzyme from the rat (Plowman \& Cleland, 1967) and chicken enzymes (Hoffmann et al., 1980b) was not observed. This was irrespective of the chloride concentration and, therefore, contrary to the observations of Plowman \& Cleland (1967) who reported that the non-linear response was abolished in the presence of $0 \cdot 25 \mathrm{M}$-chloride. Thus it is possible that the yeast ATP : citrate lyase may differ mechanistically from rat hepatic enzyme. However, this question can only be resolved by detailed kinetic studies which have not yet been performed.

Effect of divalent metal ions. The activity of the enzyme was absolutely dependent on the presence of $\mathrm{Mg}^{2+} . \mathrm{Mn}^{2+}$ and $\mathrm{Co}^{2+}$ could partially substitute, giving rates $22 \cdot 6 \%$ and $37 \cdot 1 \%$, respectively, of that observed in the presence of $\mathbf{M g}^{2+}$, when tested in the standard assay at a final concentration of $10 \mathrm{~mm}$.

Determination of molecular size. The apparent molecular weight of ATP : citrate lyase from $L$. starkeyi was determined by passing a sample of enzyme down a Sephacryl-S300 column and comparing the elution volume with the elution volumes of proteins of known molecular weight (see Methods). ATP : citrate lyase activity was recovered in a single peak with a molecular weight of 510000 (average of three determinations; highest 514000, lowest 505000). The molecular weight of the yeast enzyme was similar, therefore, to that reported for rat hepatic ATP : citrate lyase: 540000 (Linn \& Srere, 1979). 


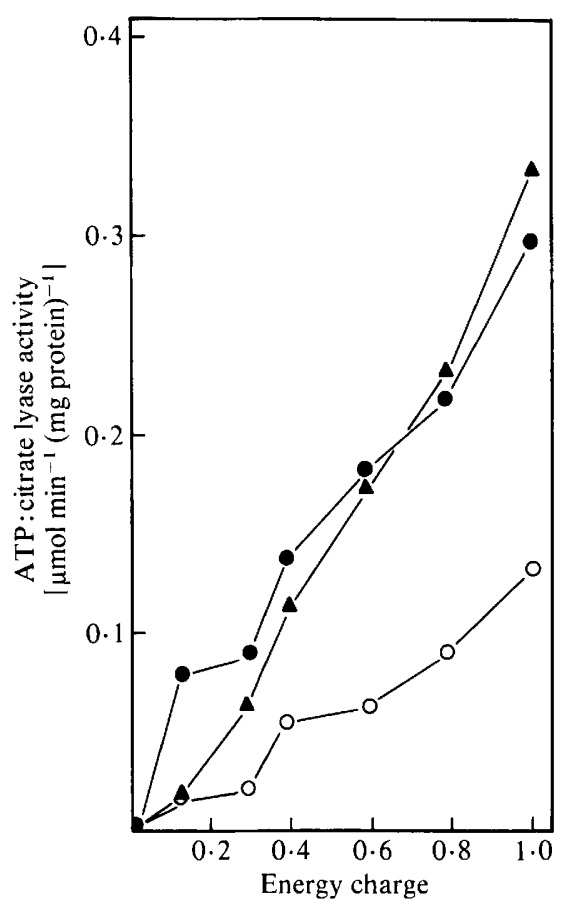

Fig. 1.

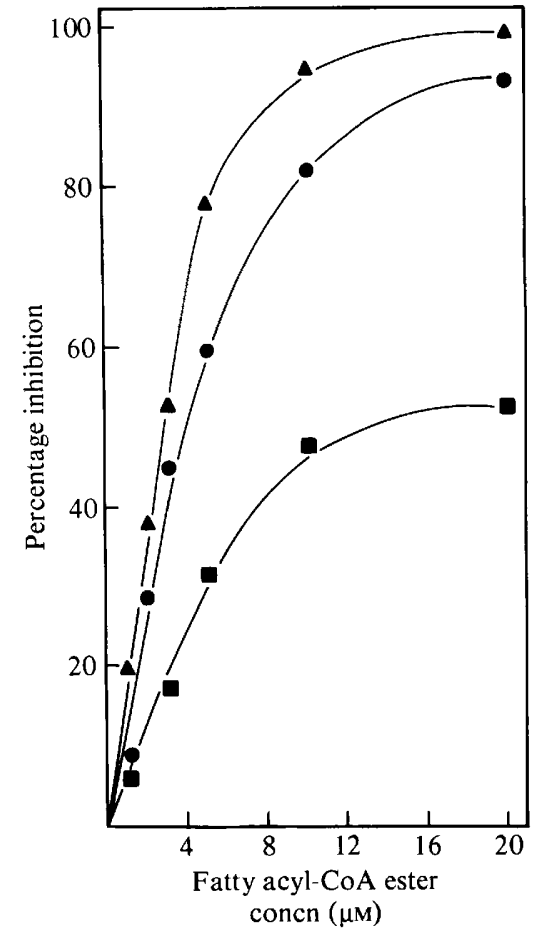

Fig. 2.

Fig. 1. Activity of ATP : citrate lyase at various simulated energy charge values [(ATP $+\frac{1}{2}$ ADP)/(ATP $+\mathrm{ADP}+\mathrm{AMP})]$ using total adenine nucleotide concentrations of $0 \cdot 1 \mathrm{mM}, 0 ; 1 \mathrm{mM}, 0$, and $10 \mathrm{mM}$, A. Reactions were initiated by the addition of coenzyme A. The proportions of each nucleotide at each energy charge value were calculated according to Bomsel \& Pradet (1968) assuming an equilibrium constant for adenylate kinase of $1 \cdot 2$.

Fig. 2. Inhibition of ATP : citrate lyase by: lauroyl-CoA, $\square$; oleoyl-CoA, $\mathbf{0}$; and palmitoyl-CoA, $\mathbf{A}$. Enzyme [specific activity: $0.81 \mu \mathrm{mol} \mathrm{min}{ }^{-1}(\mathrm{mg} \text { protein })^{-1}$ ] was incubated for $5 \mathrm{~min}$ at $30^{\circ} \mathrm{C}$ with inhibitor, at the concentration shown, prior to initiating reactions by the addition of coenzyme $\mathrm{A}$.

Effect of nucleotides on ATP : citrate lyase activity. With the exception of ADP and ATP, the mono-, di- and triphosphates of adenosine, guanosine, cytosine, uridine and inosine as well as cyclic AMP had no effect on enzyme activity when tested in the standard assay at $1 \mathrm{mM}$. ADP was a potent inhibitor of enzyme activity $(50 \%$ inhibition with $1 \mathrm{mM}$-ADP when tested in the standard assay). None of the triphosphate nucleotides tested could replace ATP as substrate, an observation contrary to that made with the rat hepatic enzyme where the partial substitution of ATP by ITP, GTP or UTP as substrate has been reported (Srere, 1975).

Since ADP is a product of the ATP : citrate lyase reaction and is inhibitory towards it, it becomes evident that enzyme activity may be regulated by changes in the relative concentrations of adenine nucleotides, i.e. by changes in the energy charge of the cell (Atkinson, 1977). Thus ATP is utilized in the synthesis of lipid, via the action of ATP : citrate lyase and also acetyl-CoA carboxylase, thereby generating ADP which, if not phosphorylated back to ATP would ultimately reduce the rates of lipogenesis by product-inhibition of ATP : citrate lyase.

ATP : citrate lyase from $L$. starkeyi responded to mixtures of adenine nucleotides simulating various energy charge values such that activity increased with increase in energy charge (Fig. 1). Furthermore, the results indicated that the relative proportion of each nucleotide, and not their absolute amounts, was of importance as an increase of 100 -fold from $0.1 \mathrm{~mm}$ to $10 \mathrm{~mm}$ total adenine nucleotide did not drastically (threefold, or so) affect enzyme activity at any particular energy charge value.

Whether this phenomenon is of regulatory importance in the control of lipogenesis in oleaginous yeasts is questionable. Previous studies with oleaginous yeasts have shown that when 


\section{Table 2. Effect of acyl-CoA esters on ATP : citrate lyase activity}

Enzyme was pre-incubated for $5 \mathrm{~min}$ at $30^{\circ} \mathrm{C}$ with the test compound prior to initiating reactions by the addition of coenzyme A. Activities are expressed relative to that observed in the absence of test compound after $5 \mathrm{~min}$ incubation at $30^{\circ} \mathrm{C}\left[0.81 \mu \mathrm{mol} \mathrm{min}^{-1}(\mathrm{mg} \text { protein })^{-1}\right]$. In a control experiment no effect was observed when each compound was included in malate dehydrogenase assays at a concentration of $100 \mu \mathrm{M}$.

\section{Compound}

Acetyl-CoA

Malonyl-CoA

Lauroyl-CoA $\left(\mathrm{C}_{12: 0}\right)$

Myristoyl-CoA $\left(\mathrm{C}_{14: 0}\right)$

Palmitoyl-CoA $\left(\mathrm{C}_{16: 0}\right)$

Steroyl-CoA $\left(\mathrm{C}_{18: 0}\right)$

Oleoyl-CoA $\left(\mathrm{C}_{18: 1}\right)$

$\begin{array}{cc}\begin{array}{c}\text { Concentration } \\ (\mu \mathrm{M})\end{array} & \begin{array}{c}\text { Activity } \\ (\%)\end{array} \\ 10 \text { or } 100 & 100 \\ 10 \text { or } 100 & 100 \\ 10 & 52 \\ 10 & 5 \\ 10 & 5 \\ 10 & 45 \\ 10 & 21\end{array}$

cultural conditions favour lipogenesis (i.e. a deficit of nitrogen with a surfeit of carbon), the adenylate energy charge is considerably higher than that observed in cultures where lipogenic rates were low (Botham \& Ratledge, 1979; Boulton, 1982), thus supporting the proposition that the control of ATP : citrate lyase activity by changes in the adenylate energy charge might be of importance in the regulation of rates of lipogenesis. However, the observed fluctuations in energy charge in the oleaginous yeasts were almost entirely due to variations in the intracellular AMP concentration rather than changes in ADP concentration. As AMP did not have any effect on ATP : citrate lyase activity, it may be that changes in the intracellular energy charge values would not influence the activity of the enzyme in vivo. Conversely, the determination of the energy charge values took no account of the undoubted intracellular compartmentalization of the adenine nucleotides. Therefore, the possibility that variations in the cytosolic pool-size of ATP and ADP might be sufficient to regulate the activity of ATP : citrate lyase in vivo cannot be entirely disregarded.

Effect of long-chain fatty acyl-CoA esters. Long-chain fatty acyl-CoA esters $\left(<\mathrm{C}_{12}\right)$ were potent inhibitors of enzyme activity (Table 2 and Fig. 2).

The following lipid intermediates and detergents had no effect on enzyme activity when tested at a final concentration of $100 \mu \mathrm{M}$ : oleic acid, oleic acid methyl ester, oleoyl alcohol, oleoyl laurate, trioleoylglycerol, oleoylacetate, palmitic acid methyl ester, palmitic acid, myristyl ester, palmityl acetate, myristoyl chloride, sodium dodecyl sulphate and Triton X-100 $(0.1 \%$, w/v).

The inhibition produced by fatty acyl-CoA esters was time-dependent so that when reactions were initiated by the simultaneous addition of coenzyme $\mathrm{A}$ and $10 \mu \mathrm{M}$-oleoyl-CoA, the initial velocity was reduced by $55 \%$, as compared with a control assay. However, when enzyme and $10 \mu \mathrm{M}$-oleoyl-CoA were pre-incubated for $15 \mathrm{~min}$ at $30^{\circ} \mathrm{C}$ prior to initiating reactions by the addition of coenzyme $A$, the inhibition increased to $98 \%$.

The inhibition by oleoyl-CoA was prevented by adding $1 \mathrm{mg}$ bovine serum albumin to assay mixtures and, perhaps more importantly, the addition of $1 \mathrm{mg}$ bovine serum albumin to mixtures of enzyme and oleoyl-CoA already pre-incubated readily reversed the inhibition.

The proposition that the inhibition of enzymes by fatty acyl-CoA esters is of regulatory significance is frequently criticized because these molecules are powerful detergents and may, therefore, exert their effects by non-specific binding or by disruption of the quaternary structure of the enzyme. However, in this case there was little evidence to support this premise. Hsu \& Powell (1975) determined the critical micellar concentration of oleoyl-CoA, a typical fatty acylCoA ester, to be $3 \mu \mathrm{M}$ in a solution whose $\mathrm{pH}$ and ionic strength were similar to those used in this present work. This value may then be taken as a measure of the detergency of these molecules. Yet oleoyl-CoA and other fatty acyl-CoA esters produced significant inhibition at concentrations below their critical micellar concentration values (Fig. 2). Furthermore, other detergents such as Triton X-100 and sodium dodecyl sulphate were not inhibitory even when tested at considerably higher concentrations. Other evidence for a regulatory role for fatty acyl- 
CoA esters in the inhibition of ATP : citrate lyase is provided by the observation that inhibition by oleoyl-CoA was readily reversible by adding bovine serum albumin. This would not be expected if the inhibition was simply due to non-specific detergent effects. The timedependency of the inhibition, in that approximately $5 \mathrm{~min}$ pre-incubation was needed to produce the maximum effect, is more difficult to explain, but we consider that this may be a consequence of using a non-homogeneous enzyme preparation such that the oleoyl-CoA may have bound non-specifically to other (inactive) proteins at the time of its addition and then been slowly and specifically acquired by the ATP : citrate lyase molecule during the pre-incubation period.

Thus, there is considerable evidence for a physiological role for the inhibition of ATP : citrate lyase from $L$. starkeyi as a means of controlling lipogenesis. This hypothesis casts some doubt, therefore, on the generally accepted premise that acetyl-CoA carboxylase is the 'first' enzyme of lipid biosynthesis and the controlling enzyme for this pathway (Volpe \& Vagelos, 1976). It is pertinent to note that the inhibitory effects of fatty acyl-CoA esters towards ATP : citrate lyase observed here are an order of magnitude higher than those reported for yeast acetyl-CoA carboxylase (Lynen, 1967; White \& Klein, 1965) including that from another oleaginous yeast, Candida 107 (Gill \& Ratledge, 1973). The inhibition of ATP : citrate lyase from L. starkeyi by fatty acyl-CoA esters represents one of the few features which so far distinguish the yeast enzyme from ATP : citrate lyase from mammalian sources, which are relatively insensitive to this form of inhibition (Bloch \& Vance, 1977). This may be explicable in that long-chain fatty acyl-CoA esters are the ultimate end-products of fatty acid biosynthesis in yeasts, whereas in mammalian tissues it is the free fatty acids that are the end-products (Bloch \& Vance, 1977). Alternatively, fatty acyl-CoA esters may arise as the first product of triacylglycerol hydrolysis. Mobilization of the lipid reserve would lead to fatty acyl-CoA esters being produced as the substrates for the $\beta$-oxidation process. Inhibition of ATP : citrate lyase by these metabolites would then be a means of preventing lipid biosynthesis whilst lipolysis was occurring.

This work was carried out with the aid of a research grant from the ARC.

\section{REFERENCES}

AtKinson, D. E. (1977). Cellular Energy Metabolism and its Regulation. New York: Academic Press.

BERGMEYER, H. U. (1974). Methods of Enzymatic Analysis. New York: Academic Press.

Bloch, K. \& VANCE, D. (1977). Control mechanisms in the synthesis of saturated fatty acids. Annual Review of Biochemistry 46, 263-298.

Bomsel, J.-L. \& PradeT, A. (1968). Study of adenosine 5'-mono-, di- and triphosphates in plant tissues. Regulation of the level of nucleotides, in vivo, by adenylate kinase: theoretical and experimental study. Biochimica et biophysica acta 162, 230-242.

Botham, P. A. \& Ratledge, C. (1979). A biochemical explanation for lipid accumulation in Candida 107 and other oleaginous micro-organisms. Journal of General Microbiology 114, 361-375.

Boulton, C. A. (1982). The biochemistry of lipid accumulation in oleaginous yeasts. Ph.D. thesis, University of Hull, U.K.

Boulton, C. A. \& Ratledge, C. (1980). Regulatory studies on citrate synthase in Candida 107, an oleaginous yeast. Journal of General Microbiology 121, $441-447$.

Boulton, C. A. \& Ratledge, C. (1981a) Correlation of lipid accumulation in yeasts with possession of ATP : citrate lyase. Journal of General Microbiology $127,169-176$.

Boulton, C. A. \& Ratledge, C. (1981 b). ATP : citrate lyase - the regulatory enzyme for lipid biosynthesis in Lipomyces starkeyi? Journal of General Microbiology 127, 423-426.

BRADFORD, M. M. (1976). A rapid and sensitive method for the quantitation of microgram quantities of protein utilizing the principle of protein-dye binding. Analytical Biochemistry 72, 248-254.

Fritsch, H. \& BeEvers, H. (1979). ATP : citrate lyase from germinating castor bean endosperm; localization and some properties. Plant Physiology 63, $687-691$.

Gill, C. O. \& Ratledge, C. (1973). Regulation of de novo fatty acid biosynthesis in the $n$-alkane utilizing yeast, Candida 107. Journal of General Microbiology 78, 337-347.

HoffmanN, G. E., Schiessl, J. \& Weiss, L. (1979). ATP : citrate (pro-3S)-lyase in the rat; two-step purification procedure, properties, organ distribution. Hoppe-Seyler's Zeitschrift für physiologische Chemie 360, 1445-1451.

Hoffmann, G. E., Andres, H., Weiss, L., Kreisel, C. \& SANDER, R. (1980a). Lipogenesis in man. Properties and organ distribution of ATP : citrate (pro-3S)lyase. Biochimica et biophysica acta 620, 151-158.

Hoffmann, G. E., Kraupe, P., Weiss, L. \& WittMANN, J. (1980b). Avian ATP : citrate (pro-3S)-lyase. Hoppe-Seyler's Zeitschrift für physiologische Chemie 361, 1117-1119. 
Hsu, K. H. L. \& Powell, G. L. (1975). Inhibition of citrate synthase by oleoyl-CoA: a regulatory phenomenon. Proceedings of the National Academy of Sciences of the United States of America 72, 47294733.

Inoue, H., Suzuki, F., Fukumishi, K., Adachi, K. \& TAKEDA, Y. (1966). Studies on ATP : citrate lyase of rat liver 1. Purification and some properties. Japanese Journal of Biochemistry 60, 543-553.

Janski, A. M., Srere, P. A., Cornell, N. W. \& VEECH, R. (1979). Phosphorylation of ATP: citrate lyase in response to glucagon. Journal of Biological Chemistry 234, 9365-9368.

KornaCKer, M. \& Lowenstein, J. M. (1963). The relation between the rates of citrate cleavage and fatty acid synthesis in rat liver preparations. Biochemical Journal 89, 27P.

KornaCKer, M. \& Lowenstein, J. M. (1965). Citrate and the conversion of carbohydrate into fat. The activities of citrate-cleavage enzyme and acetate thiokinase in livers of starved and re-fed rats. Biochemical Journal 94, 209-215.

LinN, T. C. \& SRERE, P. A. (1979). Identification of ATP : citrate lyase as a phosphoprotein. Journal of Biological Chemistry 254, 1691-1698.

LYNEN, F. (1967). The role of biotin-dependent carboxylations in biosynthetic reactions. Biochemical Journal 102, 381-400.
Mahlén, A. (1973). Purification and some properties of ATP : citrate lyase from Penicillium spiculisporum. European Journal of Biochemistry 36, 342-346.

Plowman, K. M. \& Cleland, W. W. (1967). Purification and kinetic studies of the citrate cleavage enzyme. Journal of Biological Chemistry 242, 42394247.

Redshaw, J. C. \& Loten, E. G. (1981). A rapid purification of hepatic ATP : citrate lyase using blue Sepharose. FEBS Letters 123, 261-264.

Srere, P. A. (1962). Citrate cleavage enzyme. Methods in Enzymology 5, 641-644.

SrERE, P. A. (1975). Enzymology of formation and breakdown of citrate. Advances in Enzymology 43, 57-101.

VolPe, J. J. \& Vagelos, P. R. (1976). Biosynthesis of fatty acids. Physiological Reviews 56, 339-417.

White, D. \& KLEIN, H. P. (1965). Factors affecting fatty acid synthesis in cell-free preparations from Saccharomyces cerevisiae. Biochemical and Biophysical Research Communications 20, 78-84.

YeN, C. S. \& MACK, D. O. (1980). Immunoquantitation of hepatic ATP : citrate lyase in the starved, sucroserefed, and fat-refed rat. Nutrition Reports International 22, 245-252. 